\title{
Effects of the Aqueous Extract of Oxalis Barrelieri on Some Murine Models of Acute Depression
}

\author{
Ayissi Mbomo Rigobert Espoir ${ }^{1 *}$, Mezui Christophe ${ }^{1}$, Nanga Léopold Didier ${ }^{2}$, Ndjock Roger \\ Sébastien $^{2}$, Tene Tandoum Samuel Boris ${ }^{3}$, Ngoa Manga Elisabeth ${ }^{2}$, Ngo Bum Elisabeth \\ ${ }^{I}$ Department of Biological Sciences, Higher Teacher's Training College, University of Yaoundé I, Yaoundé, \\ Cameroon \\ ${ }^{2}$ Department of Animal Biology and Physiology, Faculty of Sciences, University of Yaoundé I, Yaoundé, \\ Cameroon \\ ${ }^{3}$ Department of Neurosciences, Faculty of Medicine, University of Montréal, Canada \\ ${ }^{4}$ Department of Biological Sciences, Faculty of Sciences, University of Ngaoundéré, Ngaoundéré, Cameroon \\ *Corresponding Author: Ayissi Mbomo Rigobert Espoir, Department of Biological Sciences, Higher \\ Teacher's Training College, University of Yaoundé I, Yaoundé, Cameroon, Email: espybass@yahoo.fr
}

\begin{abstract}
Here, we examined the effects of the aqueous extract of Oxalis barrelieri (O. barrelieri) using some animal models of depression. White mice Mus musculus Swiss of both sexes, two months old where used. 30 minutes after intraperitoneal administration of $O$. barrelieri, distilled water $(10 \mathrm{~mL} / \mathrm{Kg}$ and fluoxetine $(20 \mathrm{mg} / \mathrm{kg})$, behavioral parameters were examined in the forced swimming test (FST), the tail suspension test (TST) and sugar preference test. Behavioral events including mobility were noted. In the FST, a significant increase $(p<0.01)$ in the immobility onset to $68.33 \mathrm{~s}$ and the significant reduction $(p<0.05)$ up to $33.90 \%$ of the immobility time with $\mathrm{O}$. barrelieri at doses 200 and $400 \mathrm{mg} / \mathrm{kg}$ respectively were observed. In the TST, O. barrelieri significantly increased $(p<0.01)$ up to $78.6 s$ the immobility appearance and decreased the immobility time to $28.65 \%$ at dose $200 \mathrm{mg} / \mathrm{kg}$. It was also noted a significant dose-dependent increase $(p<0.05)$, from 117, 145 and 277\%, in sweet water consumption at day 5 with doses 100,200 and $400 \mathrm{mg} / \mathrm{kg}$ respectively. These antidepressant effects, probably through monoamine mechanism would probably be due to the presence of flavonoids and saponins in the aqueous extract of $O$. barrelieri.
\end{abstract}

Keywords: Depression, Oxalis barrelieri, anhedonia, forced swimming test, tail suspension test, immobility

Abbreviations: O. barrelieri (Oxalis barrelieri), FST (Forced Swimming Test), TST (Tail Suspension Test), WHO (World Health Organization), HTTC (Higher Teacher's Training College)

\section{INTRODUCTION}

According to a report by the World Health Organization (WHO) and the World Bank Group released on June 12th, 2015, 400 million people do not have access to essential health services and $6 \%$ people in low-income countries are exposed to the extreme poverty [1]. With three of the Millennium Development Goals calling for improved health, the strategies currently being promoted by $\mathrm{WHO}$ are in the direction of security, efficiency, good quality, availability, preservation and good regulation of traditional and complementary medicine in general and more particularly medicinal plants [2].

In many countries worldwide, traditional medicine is an important and often underestimated part of health services. The use of plants to cure or prevent chronic and mental diseases has a long history dating back to antiquity; for example the lantana tree, which is known for its many antimicrobial properties; it is particularly effective against bronchitis and other respiratory infections [3].

Now days, the international community is increasingly recognizing that invisible disabilities, such as mental health, are one of the most neglected but most critical development challenges for achieving the internationally agreed development goals. The most common mental disorders are depression and anxiety. Depression, often called "evil of the century" is not a recent concept, but its origin is as far away as the memory of medical literature [4]. Depression is one of the most prevalent psychological disorders in the world [5]. This 
prevalence has doubled over the last twenty years [6] ranking depression as the fourth leading cause of disability worldwide (with a disability rate comparable to that obtained by combining all types of cancers), making this pathology a public health problem worldwide [7]. Mortality associated with depression remains high, especially in developing countries. Currently, depression has become a common disorder with significant functional, social and economic repercussions; As a result, according to the publication of the WHO, depression will become the second leading cause of disability in the world in 2020 [8]. The resulting dysfunctions, such as anhedonia, insomnia, rumination and loss of motivation, negatively influence the social, family and professional environment of these individuals who find themselves unable to fulfill their roles in the society and become in the most severe cases suicidal [9]. This alarming finding justifies the importance to develop and implement rapid and effective interventions for the treatment of depression. A variety of modern treatments is currently available to cope with the biological and psychosocial symptoms of depression [10]. Treatment with tricyclic antidepressants is the most widely used, regardless of the severity of the disease $[11 ; 12]$. Although effective in much of cases of severe and chronic depression (sometimes alone or in combination with psychotherapy), antidepressants are often not more effective than placebo [13]. Despite the widespread use of conventional known antidepressants, they still face a multitude of problems including a lack of action specificity, an impressive number of side effects and the dependence they develop when they are inappropriately used (self-medication) or long term. In addition, in developing countries like Cameroon, the high cost of conventional treatments makes them inaccessible. There are more than a thousand plants traditionally used in the world to fight against depression. These offer a vast repertoire of substances that can potentially be developed into modern pharmaceuticals for use in psychiatry. This resort to traditional medicine has led several actors to invest in ethnobotanical, pharmacological, phytochemical and technological studies [14]; this for the purpose of developing and marketing improved traditional medicines. Following this global movement, the Laboratory of Animal Physiology of the Higher Teacher's Training College (HTTC) of the University of Yaoundé I have long been involved in the study of the pharmacological properties of medicinal plant extracts. The present study focuses on Oxalis barrelieri (O. barrelieri), a plant commonly found in dry, sandy soils in some parts of the world. Despite widespread use of this plant, nothing is known about its potency to alleviate depression-like behaviors. The main objective of this work been the evaluation of antidepressant properties of the aqueous extract of $\mathrm{O}$. barrelieri on some murine models of acute depression, specific objectives include:

- The measure of the effects of O. barrelieri on the immobility of the forced swimming test paradigm;

- The measure of the effects of O. barrelieri on the immobility of the tail suspension test paradigm;

- The measure of the effects of O. barrelieri on sucrose consumption in anhedonia test.

\section{Material}

\subsection{Biological Material}

\subsubsection{Animals}

The experimental animals were white mice of both sexes belonging to Mus musculus Swiss strain, aged about two months and weighing between 18 and $30 \mathrm{~g}$. These animals all came from a colony breded at the animal house of the HTTC of Yaoundé (Cameroon). The animal house of the HTTC is established housed in a room whose environmental conditions are generally those of the surrounding environment (a normal 12-hour light cycle, an average temperature of $23^{\circ} \mathrm{C}$ and a relative humidity around 55\%). During the entire husbandry period, the animals were subjected to a controlled diet, made from a feed of well-known composition and had free access to tap water. The procedures for handling these animals have been done in strict accordance with the guidelines of the National Guide of Ethics (FWA-IRB00001954) while limiting the number and suffering of animals.

\subsubsection{Plant}

Whole plants of $\mathrm{O}$. barrelieri were collected in Yaoundé (Cameroon), at Etoudi neighborhood (palace axis, $3^{\circ} 55^{\prime} 0 " \mathrm{~N} ; 11^{\circ} 31^{\prime} 0 " \mathrm{E}$ ) from March to April 2017. The plant's identification was made at the National Herbarium of Cameroon when compared to the specimen number 24759 . The collected samples were dried in the shade room for 45 days. The leaves were crushed until a green powder was obtained, then used for the preparation of the decoction and lyophilizate. 


\subsection{Experimental Equipment and Devices}

\subsubsection{Cylindrical Glass Bowl}

The equipment used for the FST was a cylindrical transparent glass vessel $(40 \mathrm{~cm}$ high x $20 \mathrm{~cm}$ diameter), placed on a flat surface. The cylinder was filled with $20 \mathrm{~cm}$ of tap water at room temperature, to prevent the legs of the animal from touching the bottom of the cylinder and also prevent its escape through the top.

\subsubsection{Suspension Box}

The equipment used for the TST was a parallelepiped wood made cage $(60 \times 40 \times 20$ $\mathrm{cm})$ opened from the front and placed on a flat surface and comprising a suspension bar at 55 $\mathrm{cm}$ from the bottom. During the experiment, the animals were fixed by the tail on the suspension bar using adhesive tape.

\subsubsection{Anhedonia Test Device}

To evaluate sweat water consumption, each animal was placed in a cage made of small cylindrical basins of lightened plastic $(20 \times 20 \mathrm{x}$ $20 \mathrm{~cm}$ ), arranged on a flat surface. Tape and sweat water solutions were delivered to each animal by two transparent containers of $100 \mathrm{ml}$.

\section{METHODS}

\subsection{Preparation of the Decoction}

The powder made of aerial part of O. Barrelieri previously weighed (168 g) was dissolved in 4.18 $\mathrm{L}$ of distilled water, brought to a boil for 15 minutes, then leave for cooling. After cooling, the solution was filtered using Whatman $\mathrm{N}^{\circ} 3$ filter paper. The filtrate obtained was lyophilized and a crude extract powder of $34.44 \mathrm{~g}$ obtained (a yield of $20.52 \%$ ).

\subsection{Preparation of Solutions}

\subsubsection{Solution of Aqueous Extract O. Barrelieri}

Every day, a new stock solution of O. Barrelieri was prepared by introducing $400 \mathrm{mg}$ of the lyophilizate into a $10 \mathrm{~mL}$ vial. After adding distilled water to the mark and then homogenizing with a magnetic stirrer, a 40 $\mathrm{mg} / \mathrm{mL}$ concentration solution was obtained. All solutions were administered to the mice intraperitoneally at a volume of $10 \mathrm{~mL} / \mathrm{kg}$. As a result, the dose corresponding to this stock solution was $400 \mathrm{mg} / \mathrm{kg}$. By dilution to $1 / 2$ and $1 / 4$ of this stock solution in distilled water, two other doses required for the experiments (200 and $100 \mathrm{mg} / \mathrm{kg}$ respectively) were obtained.

\subsubsection{Solution of Glucose $3 \%$}

The aqueous glucose solution was prepared at a concentration of $30 \mathrm{mg} / 1000 \mathrm{~mL}$ by dilution of sucrose in distilled water.

\subsection{Distribution of Animals}

For each of the tests carried out during this work, the weighed and selected mice were divided into five groups of six animals each. Animal groups were organized as follows:

Group 1 (negative control), consisting of mice receiving only the vehicle solution (distilled water) by oral route;

Groups 2, 3 and 4 (test groups), consisting of mice treated with the aqueous extract of $\mathrm{O}$. barrelieri at doses 100; 200 and $400 \mathrm{mg} / \mathrm{kg}$ respectively;

Groupe 5 (positive control), consisting of mice intraperitoneally treated with the reference drug (fluoxetine) at dose of $20 \mathrm{mg} / \mathrm{kg}$.

\subsection{Pharmacological Tests}

\subsubsection{Forced Swimming Test}

\section{Principle}

This test, commonly used for research and investigation of new antidepressant drugs, was first described by Porsolt and his colleagues in 1977 [15]. The test is based upon the observation that a depressed animal, once in a cylinder filled with water, develops an immobile posture. Generally, after administration of antidepressant drugs, animals become more active, with behaviors oriented towards escape and reduced immobility [16].

Evaluation of the Effects of the Decoction of $O$. Barrelieri on the Forced Swimming Test Parameters

Young mice aged for eight weeks, weighing between 18 and $30 \mathrm{~g}$ were divided into 5 homogeneous groups (sex and weight) of 6 animals each as indicated in the distribution. After marking them on the tail with a permanent marker, animals of the different groups were introduced into a single cage and then had to undergo a particular treatment. For a rational labor's organization, the animals of each group received their treatments at regular intervals. 30 minutes after intraperitoneal administration of the different treatments, each animal was individually forced to swim inside a glass cylinder, filled to a height of $20 \mathrm{~cm}$ of tap water at room temperature. The behavior of each animal was then observed and recorded by a video camera for a period of 360 seconds. 
Subsequent observation of the different videos allowed the experimenters to note the parameters of the FST including the time of the first immobility appearance (s) and the total immobility time (s).

\subsubsection{Tail Suspension Test}

\section{Principle}

The TST, which was first introduced in 1985 to measure the potential efficacy of antidepressants, shares theoretical basis and behavioral measures with the FST. In general, rodents suspended by the tail at a certain height of the ground develop a behavior characterized by early agitation, followed by the development of an almost permanent still posture [17].

Evaluation of the Effect of the Decoction of $O$. Barrelieri on the Tail Suspension Test Parameters

The process of distribution and treatment were similar to those described for the FST. 30 minutes after the initial treatments, the behavior of each animal was individually observed and recorded by a camera in the TST paradigm for 360 seconds. After watching the videos, the time when the first immobility appears as well as the total immobility duration (s) were noted.

\subsubsection{Anhedonia Test}

\section{Principle}

Initially described for the first time by Willner and his colleagues in 1984, this test is based on the principle that animals subjected to a stressful stimulus show a lower preference for normally appreciated sweet foods; and these effects are reversed or corrected after the administration of various antidepressant drugs [18].

Evaluation of the Effect of the Decoction of $O$. Barrelieri on Anhedonia

The consumption of sweet water was measured in 30 animals of both sexes distributed into 5 groups as previously stated. Here 6 animals, in individual cages received a particular treatment as observed in TST and FST. The anhedonia test was spread over 5 successive days. Each animal was individually placed in a cage and different solution delivered by two bottles (tap water $100 \mathrm{~mL}$ and $100 \mathrm{~mL}$ sweet water). Bottle positions were to be rotated at 5 hour intervals to avoid addictive bias due to the contents of a single bottle. Each day, different treatments were administered to each group, and 30 minutes later animals in each group were subjected to stressful stimuli for about $30 \mathrm{~min}$. From the day 2 to day 5 , the daily consumption level of sweet water (in $\mathrm{mL}$ ), and the change in weight (in $\mathrm{mg}$ ) were recorded for each group.

\subsection{Phytochemical Screening}

Phytochemical screening of the extract of $\mathrm{O}$. barrelieri was performed to search for alkaloids, phenols, flavonoids, sterols, saponins, and triterpenes.

\subsubsection{Search for Alkaloids}

The alkaloids were characterized using Meyer's reagent. To proceed, $50 \mathrm{mg}$ of extract was dissolved in $400 \mu \mathrm{l}$ of sulfuric acid $1 \%$. After stirring, it was boiled for $3 \mathrm{~min}$ and then filtered. To $1 \mathrm{ml}$ of this filtrate, $200 \mu \mathrm{l}$ of Meyer's reagent was added. The orange color indicates the presence of alkaloid [19].

\subsubsection{Search for Flavonoids}

$50 \mathrm{mg}$ of extract of $\mathrm{O}$. barrelieri were dissolved in $800 \mu \mathrm{l}$ of distilled water, then $400 \mu \mathrm{l}$ of methanol was added; after homogenization, a few grams of magnesium chips were added. The appearance of yellow precipitates indicates the presence of flavonoids [19].

\subsubsection{Search for Triterpenes and Sterols}

$50 \mathrm{mg}$ of extract of $\mathrm{O}$. barrelieri were dissolved in $200 \mu \mathrm{l}$ of methylene chloride. 2 drops of acetic anhydride were successively added to the sulfuric acid $2 \%$. The appearance of the purplish-red color marks the presence of triterpenes while the blue color characterizes the presence of sterols [19].

\subsubsection{Search for Saponins}

$50 \mathrm{mg}$ of extract $\mathrm{O}$. barrelieri were mixed with $800 \mu$ of distilled water and the whole was brought to the water bath for $5 \mathrm{~min}$. After cooling, the mixture was vortexed until the appearance of increasingly thick foam, indicating the presence of saponins [19].

\subsubsection{Search for Tanins}

$50 \mathrm{mg}$ of extract were dissolved in $800 \mu \mathrm{l}$ of distilled water and the whole was heated in a water bath for 5 minutes. After cooling, $50 \mu 1$ of ferric chloride $3 \%$ were added. Obtaining the green or blackish color indicates the presence of catechic tanins and the dark blue coloring of the galic tanins [19].

\subsection{Data Analysis}

Data were processed using SPSS (Statistical Package of Social Sciences) software version 20.0 for Windows and expressed as mean \pm SEM. Data related to different parameters were subjected to analysis of variance (ANOVA), 
then the averages compared by Dunnet's posthoc test, the $\mathrm{P}$ value less than 0.05 was considered statistically significant.

\section{RESUlts}

\subsection{Forced Swimming Test}

\subsubsection{Effect of the Decoction of O. Barrelieri on the}

Figure 1 shows that the immobility onset increased from $60 \pm 0.58 \mathrm{~s}$ in mice of the negative control group to $79.5 \pm 0.54 \mathrm{~s}$ in mice treated with fluoxetine $20 \mathrm{mg} / \mathrm{kg}$. Administration of doses 100 and $400 \mathrm{mg} / \mathrm{kg}$ of $\mathrm{O}$. barrelieri resulted in a significant increase $(\mathrm{p}<0.05)$ of 67 $\pm 0.8 \mathrm{~s}$ and $68.33 \pm 0.46 \mathrm{~s}$ respectively, compared to the negative control group, and the effect produced by the plant at these two doses represents 94 and 95\% respectively of those provided by the reference drug fluoxetine.

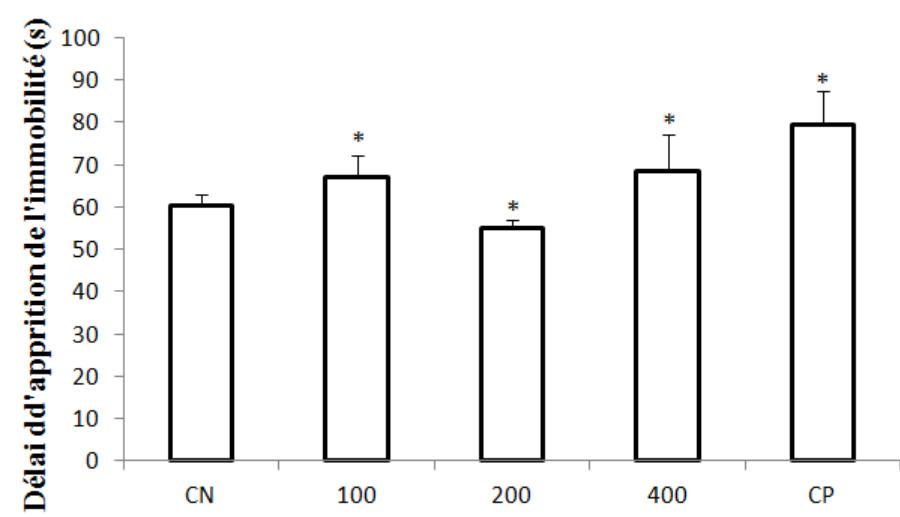

Figure1. Effects of the decoction of $O$. barrelieri on the time of immobility occurrence in the FST

Each bar represents the average of the time of onset of immobility $(s)+S E M$; with $n=6 .{ }^{*} p<0.05$, significant difference compared to the negative control group that received distilled water. $C N=$ negative control; 100 , 200 and $400=$ decoction of $\mathrm{O}$. barrelieri at doses $100,200,400 \mathrm{mg} / \mathrm{kg}$ respectively; $C P=$ positive control (treated with fluoxetine $20 \mathrm{mg} / \mathrm{kg}$ ).

\subsubsection{Effects of the Decoction of $O$. Barrelieri on the Total Immobility Time in the FST}

Mice treated with the extract of $\mathrm{O}$. barrelieri spent less time immobile when compared to mice of the negative control group. In fact, the total immobility time decreases from an average value of $295 \pm 0.47 \mathrm{~s}$ with the animals of the negative control group to a significant average value $(\mathrm{p}<0.05)$ of $195 \pm 0.6$ with the highest dose $(400 \mathrm{mg} / \mathrm{kg})$ of $\mathrm{O}$. barrelieri. As expected, for the positive control, fluoxetine administered intraperitoneally at a dose $20 \mathrm{mg} / \mathrm{kg}$ induced a significant decrease $(\mathrm{p}<0.05)$ of the total immobility time at $208.5 \pm 0.73 \mathrm{~s}$, representing for about $30 \%$ reduction of the effect observed with animals treated with distilled water (Figure 2).

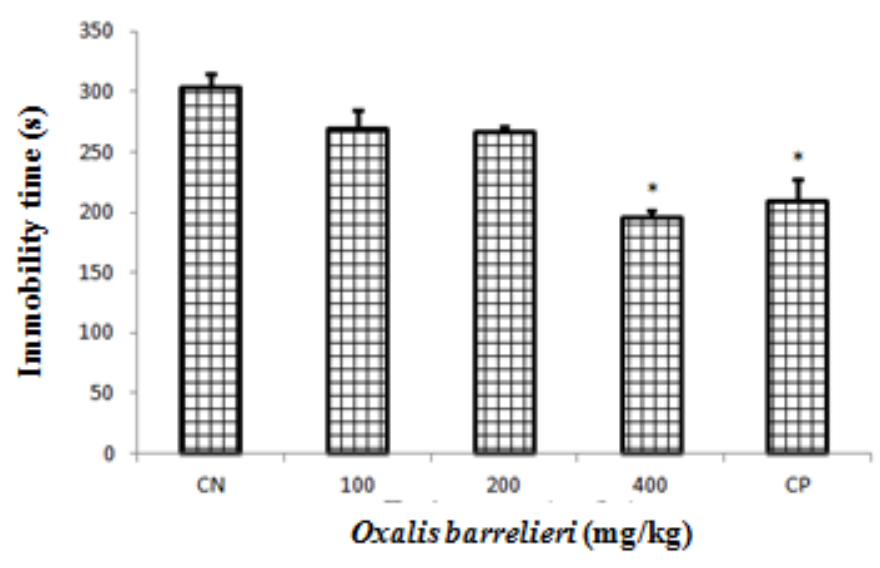

Figure2. Effects of the decoction of $O$. barrelieri on the total immobility time in FST.

Each bar represents the mean duration of the immobility $(s)+S E M$; with $n=6$. * $p<0.05$, significant difference compared to the negative control group treated with distilled water. $C N=$ negative control; 100,200 and $400=$ decoction of $O$. barrelieri at doses 100, 200, $400 \mathrm{mg} / \mathrm{kg}$ respectively; $C P=$ positive control (treated with fluoxetine at dose $20 \mathrm{mg} / \mathrm{kg}$ ). 


\subsection{Tail Suspension Test}

\subsubsection{Effect of the Decoction Of O. Barrelieri on the Delay of Immobility Appearance}

Figure 3 show that the time of immobility onset significantly increases $(p<0.01)$ after treatment with increasing doses of $\mathrm{O}$. barrelieri. The time of immobility appearance falls from $30.75 \pm$
$0.55 \mathrm{~s}$ in animals treated with distilled water to $64.8 \pm 0.34 \mathrm{~s}$ in animals treated with the dose $200 \mathrm{mg} / \mathrm{kg}$, then $78.6 \pm 1.10 \mathrm{~s}$ in mice treated with O. barrelieri at dose $400 \mathrm{mg} / \mathrm{kg}$, representing approximately an increase of $110 \%$ and $149 \%$ respectively. The first immobility appears after $78.5 \pm 0.43 \mathrm{~s}$ in the group treated with the reference drug.

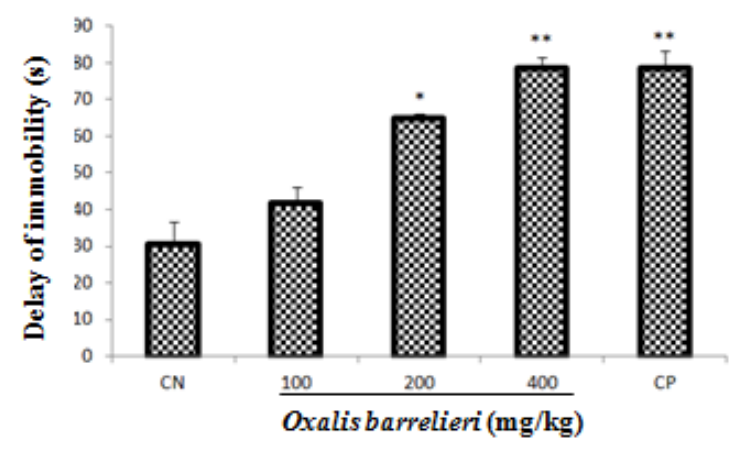

Figure3. Histogram showing the effect of the aqueous extract of $O$. barrelieri on the time of immobility onset in the TST

Each bar represents the average time of immobility (s) appearance $+S E M$; with $n=6 . * p<0.05 ; * * p<0.01$ significant difference compared to the negative control lot that received distilled water. $C N=$ negative control; 100,200 and $400=$ decoction of $O$. barrelieri at doses 100,200, $400 \mathrm{mg} / \mathrm{kg}$ respectively; $C P=$ positive control (treated with fluoxetine dose $20 \mathrm{mg} / \mathrm{kg}$ ).

4.2.2. Effects of the Decoction of $O$. Barrelieri on the Immobility Time in the TST

The mean duration of immobility decreased in mice treated with the aqueous extract of $\mathrm{O}$. barrelieri in comparison to the negative control mice treated with distilled water (Figure 4). The total immobility time decreased from the mean value of $208.5 \pm 0.56 \mathrm{~s}$ in the negative control group to $173.25 \pm 0.65 \mathrm{~s}$ and $175 \pm 0.43 \mathrm{~s}$ in the mice treated with doses 100 and $400 \mathrm{mg} / \mathrm{kg}$ of O. barrelieri, respectively. The more marked significant reduction $(p<0.05)$ in the duration of immobility of $148.75 \pm 0.75 \mathrm{~s}$ and $161 \mathrm{~s} \pm 0.35 \mathrm{~s}$ were achieved with fluoxetine and dose 200 $\mathrm{mg} / \mathrm{mg}$, respectively, representing reduction of $22.59 \pm 0.65 \mathrm{~s}$ and $28.65 \%$ respectively in comparison with the negative control group.

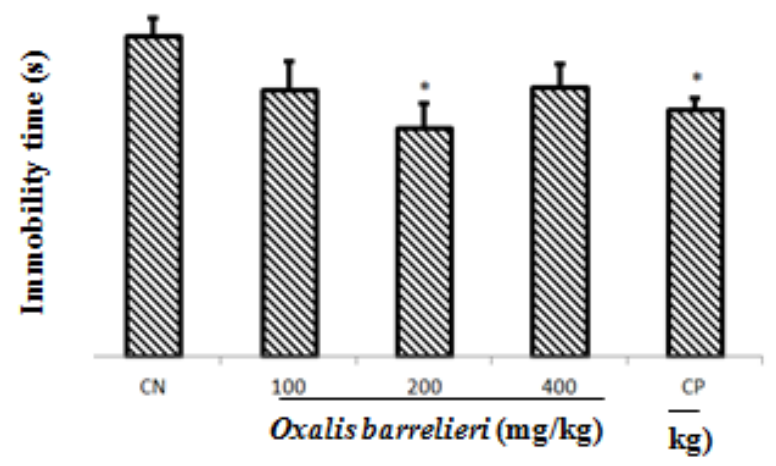

Figure4. Effects of the decoction of $O$. barrelieri on the average immobility duration

Each bar represents the mean of the immobility duration $(s)+S E M$; with $n=6 .{ }^{*} p<0.05$ significant difference compared to the negative control group that received distilled water. $C N=$ negative control; 100, 200 and $400=$ decoction of $O$. barrelieri at doses 100, 200, $400 \mathrm{mg} / \mathrm{kg}$ respectively; $C P=$ positive control (treated with imipramine at dose $20 \mathrm{mg} / \mathrm{kg}$ ).

\subsection{Sucrose Preference Test}

\subsubsection{Effect of the Decoction of O. Barrelieri on Mice Body Mass}

At day 1, all groups had substantially equal body weight averages ranging from $22.15 \pm 0.68$ $\mathrm{g}$ to $24.7 \pm 1.39 \mathrm{~g}$. Between day 1 and day 5 , in the negative control group, a significant decrease $(\mathrm{p}<0.05)$ of the animal's body mass of $9 \%$ (from $24.7 \pm 1.39 \mathrm{~g}$ to $22.5 \pm 1.45 \mathrm{~g}$ ) was observed. Contrary, in all the groups treated with the decoction of $\mathrm{O}$. barrelieri, between day 
1 and day 5, a significant increase in the average body mass was observed, corresponding to the percentages of $11.87,11.70$ and $20 \%$ for doses 100,200 and $400 \mathrm{mg} / \mathrm{kg}$ respectively. As expected, the treatment of animals with fluoxetine also resulted in a significant increase $(\mathrm{p}<0.01)$ of body mass of nearly $4.5 \mathrm{~g}(18.66 \%)$.
At day 5, the average body mass of mice in the negative control group of $22.5 \pm 0.49 \mathrm{~g}$, significantly increased $(\mathrm{p}<0.05)$ at $26.28 \mathrm{~g} \pm$ $0.81 \mathrm{~g}$ and $28.36 \pm 1.02 \mathrm{~g}$ with dose $400 \mathrm{mg} / \mathrm{kg}$ and fluoxetine respectively (increase of 18 and $26 \%$ respectively) (Figure 5).

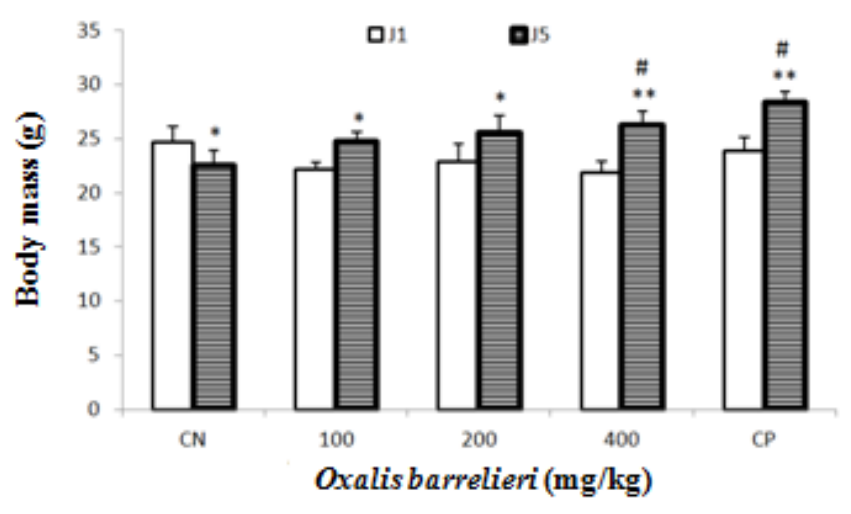

Figure5. Effects aqueous extract of $O$. barrelieri on the variation of body mass

Each bar represents the average body mass $(g)+S E M$; with $n=6 . * p<0.05 ; * * p<0.01$ significant difference comparison between day 1 and day $5 \# p<0.05$ significant difference in comparison with the negative control group at day 5. $C N=$ negative control; 100, 200 and $400=$ decoction of $O$. barrelieri at doses 100, 200, 400 $\mathrm{mg} / \mathrm{kg}$ respectively; $\mathrm{CP}=$ positive control (treated with fluoxetine at dose $20 \mathrm{mg} / \mathrm{kg}$ ), J1 and J5 = day 1 and day 5 of experiments respectively.

\subsubsection{Effects of the decoction of $O$. barrelieri on daily consumption of sweet water}

Between day 2 and day 5, in the negative control group, the sweet water consumption decreased from an average volume of $2.8 \pm 0.47$ $\mathrm{mL}$ to $1.75 \mathrm{~mL} \pm 0.47$; a significant reduction of about $40 \%(\mathrm{p}<0.05)$ (Figure 6). In different test groups, from day 2 to day 5 , a dose-dependent increase (not significant from the 2 nd to the 4 th day) of sweet water consumption was observed with significant maximum values of $3.8 \pm 0.70$
$\mathrm{mL}, 4.3 \pm 0.53 \mathrm{~mL}$ and $6.6 \pm 0.49 \mathrm{~mL}$ (ie increases of 117,145 , and $277 \%$ ) observed on day 5, at doses 100, 200, and $400 \mathrm{mg} / \mathrm{kg}$ respectively. A similar variation in sweet water consumption to that observed in animals treated with dose $400 \mathrm{mg} / \mathrm{kg}$ was observed in the positive control treated with the well-known reference drug (Figure 6).

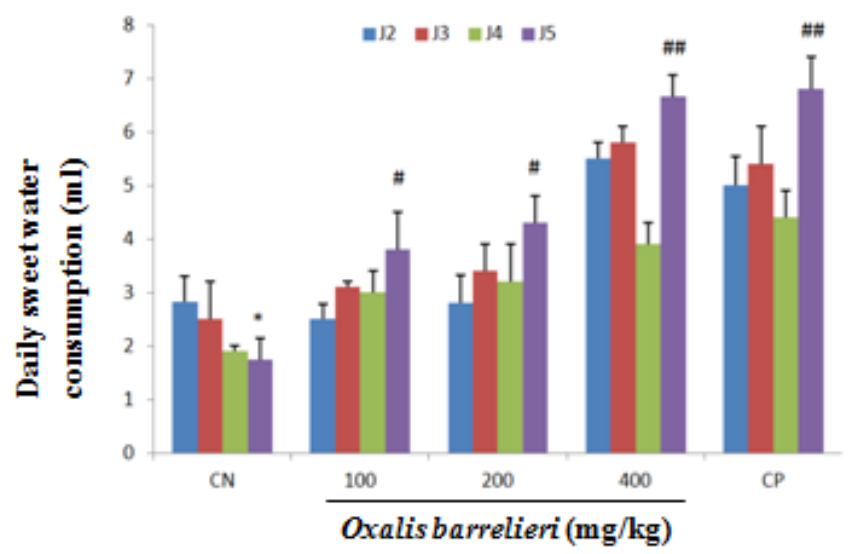

Figure6. Effects of $O$. barrelieri on daily sweet water consumption

Each bar represents the average volume of sweet water consumed $(m L)+S E M$; with $n=6 .{ }^{*} p<0.05$; significant difference in comparison between the 2 nd and the 5th day in the negative control group. \# $p<0.05$, \#\# $p<0.01$ significant difference in comparison with the negative control group from day 2 to day 5 . CN = negative control; 100, 200 and $400=$ decoction of $O$. barrelieri at doses 100, 200, $400 \mathrm{mg} / \mathrm{kg}$ respectively; CP = positive control (treated with fluoxetine at dose $20 \mathrm{mg} / \mathrm{kg}$ ). J2, J3, J4 and J5 = day 2, day 3, day 4 and day 5 of experiments respectively 


\subsubsection{Effects of the decoction of O. barrelieri on total sweet water consumption}

From Figure 7, it appears that the total volume of sweet water consumed is about $9 \mathrm{~mL}$ in the negative control group. The administration of varying doses of the decoction of $\mathrm{O}$. barrelieri

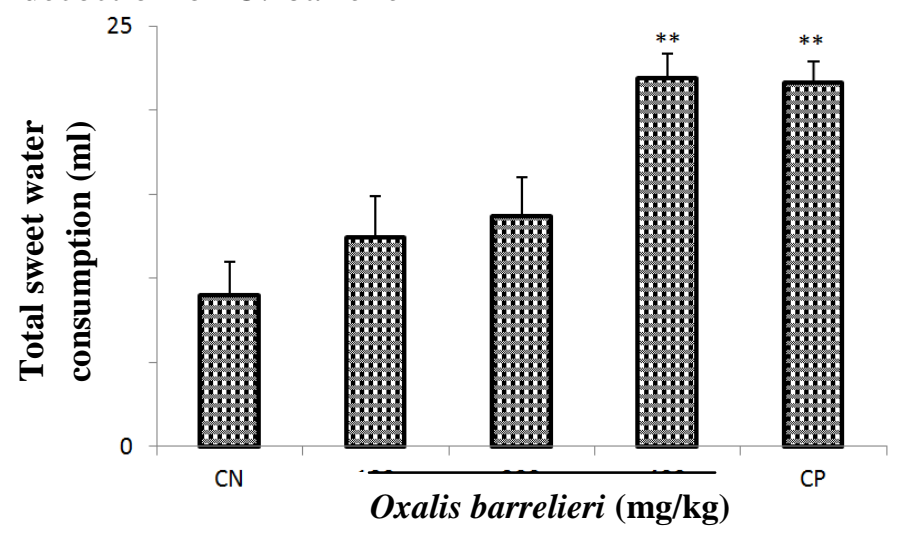

Figure7. Effects of $O$. barrelieri on the total sweet water consumption

Each bar represents the average of the amount of sweet water consumed $(m L)+S E M$; with $n=6 .{ }^{* *} p<0.01$ significant difference compared to the negative control group $C N=$ negative control; 100,200 and $400=$ decoction of $O$. barrelieri at doses 100,200, $400 \mathrm{mg} / \mathrm{kg}$ respectively; $C P=$ positive control (treated with fluoxetine at dose $20 \mathrm{mg} / \mathrm{kg}$ ).

\subsection{Phytochemistry}

The result of qualitative phytochemical analysis showed that the aerial parts of aqueous extract

Table1. Qualitative phytochemical composition of the aerial parts aqueous extract of $O$. barrelieri

\begin{tabular}{|l|l|l|l|l|l|l|l|l|}
\hline Phenols & Polyphenols & $\begin{array}{l}\text { Cathechic } \\
\text { tanins }\end{array}$ & $\begin{array}{l}\text { Galic } \\
\text { tanins }\end{array}$ & Flavononoids & Alkaloids & Saponins & Triterpens & Sterols \\
\hline+ & ++ & +++ & - & ++ & - & ++ & + & - \\
\hline
\end{tabular}

\section{DISCUSSION}

The doses used in this study were chosen based on previous studies conducted on this plant in our laboratory [20], and the therapeutic properties of $\mathrm{O}$. barrelieri against depression like-behaviors have been studied scientifically in vivo, using three classical animal models of depression including the forced swimming, tail suspension, and anhedonia tests. The FST is one of the most commonly used models for evaluating the activity of potential antidepressants. This test is often used in rodents to study the antidepressant activity of the drugs by evaluating the decrease of the total immobility time [15], and this immobility been the main behavioral parameter noted, resembling a behavioral state of resignation, as seen in human depression [17]. In the FST, the mice are forced to swim in a restricted space from which they can not escape and are activated for a immobility behavior. This behavior demonstrates a state of hopelessness that can be diminished by antidepressants used to treat depression in human [17]. Our results of $\mathrm{O}$. barrelieri possess phenols, polyphenols, cathechic tanins, flavonoïds, saponins and triterpens (Table 1). show that the different doses of O. Barrelieri and fluoxetine influenced immobility scores (immobility onset time and immobility time) in contrast to mice treated with a vehicle solution. The main results of the FST indicate that, in the O. barrelieri-treated mice, the immobility time decreases, while the delay of immobility appearance increases, suggesting the presence in O.barrelieri extract of compounds responsible for the antidepressant effects.

For example, the administration $\mathrm{O}$. barrelieri dose at $400 \mathrm{mg} / \mathrm{kg}$ provides $95 \%$ of the effect observed with the reference drug. These results are correlated with those of Porsolt et al, as well as those of Kulkarni and Mehta who have demonstrated that a net increase in swimming activity implies the antidepressant activity of the substance used [16, 21]. In the TSC as described by Steru and his colleagues, the mice were hung by the tail, using tape to a rod, at $60 \mathrm{~cm}$ above the ground. Each trial was conducted for a period of 6 minutes and the main behavioral measure was the duration of immobility, also interpreted as behavioral hopelessness [17]. 
During the TSC, it was observed a dosedependent and significant increase $(p<0.01)$ in immobility occurrence for doses 200 and 400 $\mathrm{mg} / \mathrm{kg}$, when compared to control group mice; only the dose $400 \mathrm{mg} / \mathrm{kg}$ showed effects nearly to fluoxetine. Moreover, at dose $200 \mathrm{mg} / \mathrm{kg}$ O.barrelieri significantly $(p<0.05)$ decreased the mean duration of immobility when compared to the negative control animals. This result corroborates with those of Steru et al and Perrault who suggest that an antidepressant substance administered before the TST reverses immobility and promotes fighting behavior [17; 22]. Anhedonia is a paradigm where rodents are usually chronically exposed to a series of mild stressors and their sugar solution consumption monitored. the chronic moderate stress (CMS) in rodents, originally developed by Willner, represents the animal model the most suitable for studying the pathophysiology of mood disorders as well as their treatment. This animal model is very relevant since it allows inducing behavioral states close to the symptoms observed in the depression in humans [23; 24]. Stressed animals tend to consume less sugar, suggesting an induction of a mild anhedonic state by stress [18; 25]. During this test, the parameters recorded in mice treated with aqueous extracts of $\mathrm{O}$. barrelieri were the total sweat water consumption, the body mass variation between day 2 and day 5, and shift in daily sucrose consumption. During this work, we noticed a significant $(p<0.05)$ decrease of the body mass in the negative control group between day 1 and day 5 . In the negative control group over a five days treatment, it was noticed a significant decrease $(\mathrm{p}<0.05)$ of mice body mass. On the other hand, a dose-dependent increase of the body mass of the groups treated with $\mathrm{O}$. barrelieri when compared to negative control group. Similarly concerning the total consumption of sweat water, it was observed a significant $(\mathrm{p}<0.01)$ dose-dependent increase in total volume of sweat water consumed for the different doses of $\mathrm{O}$. barrelieri. Regarding the daily consumption of sweat water, the results obtained, show a significant reduction $(\mathrm{p}<0.05)$ between day 2 and day 5 in the negative control group thus inducing a loss of about $40 \%$ on the starting body mass. In contrast, the body mass of mice treated with $\mathrm{O}$. barrelieri and fluoxetine increased. A stressed mouse is characterized by depressive-like behaviors [26]. The diminished exploration of novelty and sweat food consumption, the loss of body weight are the consequences of chronic stress and thus the development of anhedonia state. Previous studies conducted by David and his team in 2009 , through predictive tests of the activity of fluoxetine (selective serotonin reuptake inhibitor) and imipramine (tricyclic), show that chronic treatment with each of these antidepressants blocks the behavioral alterations induced by long-term exposure to corticosterone [26]. In this study the effects of the reference drug (fluoxetine) are comparable to those obtained with $\mathrm{O}$. barrelieri, so it may be suggested that like fluoxetine; Furthermore, results also indicate the presence of large amounts of flavonoids in the extract of $\mathrm{O}$. Barrelieri. Previous studies by Freitas et al. in 2014 and Mai et al. in 2015 reported that many flavonoids possess antioxidant, antiinflammatory, and antidepressant activities in animal studies [27, 28]. The monoamine theory of depression indicates that, the main biochemical causes of depression are metabolic disorders of monoamine neurotransmitters that are involved in NE, 5-HT, and DA signaling $[29,30]$. Thus, the anxiolytic-antidepressant effects of $O$. barrelieri, could involve mechanisms both dependent and independent of the neurogenesis process in many brain areas by setting of a new physiological state, which would probably facilitate an increase of monoamines (serotonin) action [31; 32]. Moreover, the phytochemical study of $\mathrm{O}$. Barrelieri has revealed the presence of saponins. The antidepressant action of theses saponins would be to prevent the analgesic action of morphine and inhibit the development of tolerance and physical dependence caused by morphine.

There is a reduction in hypersensitivity of dopamine receptors [33], the function of dopamine been perseverance, pleasure, reward.

As a result, the antidepressant effect of the decoction of $\mathrm{O}$. Barrelieri could be explained by the inhibition of morphine synthesis by the neurons.

\section{CONCLuSiON}

At the end of this work, which focused on evaluating antidepressant properties of aqueous extract of $O$. barrelieri on some murine models of depression it follows that: Aqueous extract of $O$. Barrelieri increases the time of onset of immobility and decreases the time of immobility in the forced swimming and tail suspension tests. The aqueous extract of $O$. barrelieri increases the body mass of the mice as well as the daily and total consumption of sweet water. The main observation that emerges is that, 
without proven toxic effects, $O$. barrelieri has antidepressant properties probably induced by constituents such as, flavonoids and saponins.

\section{REFERENCES}

[1] Berthélemy J-C., Relationships between health, development and poverty reduction, $C . R$. Biologies 331 (12), 903-918 (2008)

[2] Rocío AM., Pardo-de-S., Caroline P., Ramón M., Michael H., Medicinal and local food plants in the south of Alava (Basque Country, Spain), J. Ethnopharmacol 176, 207-224 (2015)

[3] Alitonou G., Avlessi F., Bokossa I., Ahoussi E., Dangou J., Sohounhloué DC., Composition chimique et activités biologiques de l'huile essentielle de Lantana camara Linn, C.R. Chimie 10-11 (7), 1101-1105 (2004)

[4] Burton R., The Anatomy of Melancholy. Bradbury and Evans Printers; Whitefriars, London (1845)

[5] Bridget EW., Kathryn L., Blanforda, Ashley M., Butler., Estimated Prevalence of Psychiatric Comorbidities in U.S. Adolescents With Depression by Race/Ethnicity, 2011-2012, J Adolesc Health 62 (6), 716-721 (2018)

[6] Compton WM., Conway KP., Stinson FS., Grant BF., Changes in the prevalence of major depression and comorbid substance use disorders in the United States between 19911992 and 2001-2002, Am J Psychiatry 163(12), 2141-7 (2006)

[7] Brinda EM., Rajkumar AP., Attermann J., Gerdtham UG., Kuruthukulangara SJ., Health, Social, and Economic Variables Associated with Depression Among Older People in Low and Middle Income Countries: World Health Organization Study on Global AGEing and Adult Health, Am J Geriatr Psychiatry 24(12), 1196-1208 (2016)

[8] Murray CJ., Lopez AD., Alternative projections of mortality and disability by cause 1990-2020: Global Burden of Disease Study, Lancet 349(9064), 1498-1504 (1997)

[9] Murray CJ., Lopez AD., Global mortality, disability, and the contribution of risk factors: Global Burden of Disease Study, Lancet 349(9063), 1436-42 (1997)

[10] Segata J., La cosmopolitique de la dépression : biosocialité dans une ethnographie multiespèces, Vibrant Virtual Braz Anthr 12 (1), 290-320 (2015)

[11] American Psychiatric Association, Diagnostic and statistical manual of mental disorders, (4th ed., text revision). Washington, DC: American Psychiatric Association (2000)

[12] American Psychiatric Association, Diagnostic and Statistical Manual of Mental Disorders (5th ed.). Arlington: American Psychiatric Association (2013)
[13] Fournier J., DeRubeis RJ., Hollon SD., Dimidjian S., Amsterdam J., Shelton R., Antidepressant drug effects and depression severity: A patient-level meta-analysis, JAMA 303, 47-53 (2010)

[14] Keita BJ., Ulcères gastro-duodénaux en chirurgie « $B$ » Hôpital du point « $G$ », Thèse de médecine, Université de Bamako, Faculté de Médecine de Pharmacie et d'OdontoStomato logie, Mali (1990)

[15] Porsolt RD., Le Pichon M., Jalfre M., Depression: a new animal model sensitive to antidepressant treatments, Nature 266, 730-732 (1977)

[16] Kulkarni SK., Mehta AK., Purine nucleosidemediated immobility in mice: reversal by antidepressants, Psychopharmacol (Berl) 85, 460-463 (1985)

[17] Steru L., Chermat R., Thierry B., Simon P., The tail suspension test: a new method for screening antidepressants in mice, Psychopharmacol (Berl) 85, 367-370 (1985)

[18] Willner P., The validity of animal models of depression, Psychopharmacol (Berl) 83(1), 116 (1984)

[19] Tiwari P., Kumar B., Kaur M., Kaur G., Kaur, H. Phytochemical screening and Extraction: A Review, Int Pharm Sci 1, 98-106 (2011)

[20] Suzuki E., Yagi G., Nakaki T., Kamba S., Asai M., Elevated plasma nitrate levels in depressive states, J Affect Disord 63, 221-224 (2001)

[21] Perrault G., Morel E., Sanger DJ., Zivkovic B., Lack of tolerance and physical dependence upon repeated treatment with the novel hypnotic zolpidem, J Pharmacol Exp Ther 263 (1), 298-303(1992)

[22] Holsboer F., How can we realize the promise of personalized antidepressant medicines? Nat Rev Neurosci 9(8), 638-46 (2008)

[23] Grippo AJ., Sullivan NR., Damjanoska KJ., Crane JW., Carrasco GA., Shi J., Chen Z., Garcia F., Muma NA., Van de Kar LD., Chronic mild stress induces behavioral and physiological changes, and may alter serotonin 1A receptor function, in male and cycling female rats, Psychopharmacol 179, 769-780 (2005)

[24] Geyer MA., Markou A., Animal models of psychiatric disease. In: Bloom FE, Kupfer DJ, editors. Psychopharmacology: The Fourth Generation of Progress. New York: Raven Press, pp 787-798 (1995)

[25] Krishnan V., Han MH., Graham D L., Berton O., Renthal W., Russo S.J., Laplant Q., Graham A., Lutter M., Lagace DC., Ghose S., Reister R., Tannous P., Green TA., Neve, RL., Chakravarty S., Kumar A., Eisch AJ., Self DW., Lee FS., Tamminga CA., Cooper DC., Gershenfeld HK., 
Nestler EJ., Molecular adaptations underlying susceptibility and resistance to social defeat in brain reward regions, Cell 131(2), 391-404 (2007)

[26] David DJ., Samuels BA., Rainer Q., Wang JW., Marsteller D., Mendez I., Drew M., Craig DA., Guiard BP., Guilloux JP., Artymyshyn RP., Gardier AM., Gerald C., Antonijevic IA., Leonardo ED., Hen R., Neurogenesis dependant and independent effects of fluoxetine in an animal model of anxiety/depression, Neuron 62, 479-93 (2009)

[27] Freitas M., Ribeiro D., Tomé SM., Silva AMS., Fernandes E., Synthesis of chlorinated flavonoids with anti-inflammatory and proapoptotic activities in human neutrophils, Eur. J. Med. Chem 86,153-164 (2014)

[28] Mai LH., Chabot GG., Grellier P., Quentin L., Dumontet V., Poulain C., Espindola LS., Michel S., Vo HT., Deguin B., Grougnet R., Antivascular and anti-parasite activities of natural and hemisynthetic flavonoids from New Caledonian Gardenia species (Rubiaceae), Eur J Med Chem 93, 93-100 (2015)

[29] Li YC., Shen JD., Li J., Wang R., Jiao S., Yi LT., Chronic treatment with baicalin prevents the chronic mild stress-induced depressive-like behavior: involving the inhibition of cyclooxygenase-2 in rat brain, Prog. Neuro Psychopharmacol. Biol. Psychiatry 40, 138-143 (2013)
[30] Guan LP., Liu BY., Antidepressant-like effects and mechanisms of flavonoids and related analogues, Eur J Med Chem 121, 47-57 (2016)

[31] Santarelli L., Saxe M., Gross C., Surget A., Battaglia F., Dulawa S., Weisstaub N., Lee J., Duman R., Arancio O., Belzung C., Hen R., Requirement of hippocampal neurogenesis for the behavioral effects of antidepressants, Science 301, 805-9 (2003)

[32] Wang JW., David DJ., Monckton JE., Battaglia F., Hen $\mathrm{R}$ Chronic fluoxetine stimulates maturation and synaptic plasticity of adultborn hippocampal granule cells. J Neurosci 28, 137 4-1384 (2008)

[33] Kim HS., Oh KW., Lee MK., Choi KJ., Kim SC., Effects of ginseng total saponin on the development of acute and delayed typed tolerance to morphine, Kor J Ginseng Sci 13, 239-241 (1989)

Citation: Ayissi Mbomo Rigobert Espoir, et al, Effects of the Aqueous Extract of Oxalis Barrelieri on Some Murine Models of Acute Depression. ARC Journal of Neuroscience. 2019; 4(3):9-19. doi:dx.doi.org/10.20 431/2456-057X 0403002.

Copyright: (c) 2019 Authors. This is an open-access article distributed under the terms of the Creative Commons Attribution License, which permits unrestricted use, distribution, and reproduction in any medium, provided the original author and source are credited. 